\title{
The Role of the Camat in Coordinating the Administration of Peace and Order in Pangkalan Kerinci District Pelalawan Regency
}

\author{
Takimahi Subhayano ${ }^{1}$, Moris Adidi Yogia ${ }^{2}$, Made Devi Wedayanti ${ }^{3}$ Zainal $^{4}$ \\ Universitas Islam Riau, Jl. Kaharuddin Nasution No.113 Pekanbaru 28284, Riau \\ takimahikim18@gmail.com¹,moris.adidiy@soc.uir.ac.id², madedeviwedayanti@soc.uir.ac.id², \\ zainal.ip@soc.uir.ac.id ${ }^{4}$
}

\begin{abstract}
The purpose of this study is to find out the Sub District Administrator's Taskin Coordinating the Administration of Peace and Public Order in Pangkalan Kerinci SubDistrict, Pelalawan Regency. The type of research used in this research is descriptive qualitative. In this study the key informants in this study were individuals who were involved in Peace and Order in the Pangkalan Kerinci District. As for the Sub-District Head, Village/Kelurahan Head. The results of the research are the implementation of the Sub-District Head's task of coordinating peace and order in Pangkalan Kerinci Subdistrict quite well, where the Pangkalan Sub-District Head has carried out various ways through coordination with the Village/Kelurahan Government as well as Community and Police Institutions in the District Pangkalan Kerinci, even coordinating with the community which is the object of the services carried out by the District. Where the subdistrict head is present in an undisciplined and orderly manner maintained by the community and receives reports on security disturbances, asthehead of the sub-district always tries to provide a solution by referring to the applicable regulations, as well as making deliberations involving various parties involved in achieving peace andorder.
\end{abstract}

Keywords: Task, Coordination, Peace, Order

\section{Introduction}

The District Government is a concrete manifestation of a formal organization that functions to carry out the Government's functions in general in serving the community. Subdistrict institutions can be said as the administration of Government bureaucracy which is at a level higher than that of the Village or Village Government in improving its services to the community. The Camat in this case as the leader of the District Government organization is expected to be able to carry out itsfunctions. The implementation of the Regional Autonomy policy encourages structural, functional and cultural changes in the overall structure of the Regional Administration, one of the most essential changes is that which holds the position, authority and duties of the Camat.

The position of the Camat is no longer domiciled as the head of the District area and as a tool of the central government in carrying out deconcentration tasks, but has been turned into a Regional apparatus that has a portion of the authority of Regional Autonomy and the administration of Government is regulated in Law Number 23 of 2014. On Article 225 paragraph 1 Law 23 of 2014 outlines some of the main tasks of the Camat, then the details are explained in Government Regulation Number 17 of 2018 concerning Subdistricts in the implementation of Camat duties in the administration of government. Government Regulation Number 17 of 2018 concerning Sub-districts where Article 10 point c states that the Camat in 
the lead of the Sub-District is tasked with coordinating efforts to administer public order and peace,including:

a) Synergy with the Republic of Indonesia National Police, the Indonesian National Army, and Vertical Agencies in the District Region;

b) Harmonization of Relationships with Religious and Community Leaders ;and

c) Reporting on the Implementation of Peace and Order Development to Regents / Mayors .

The implementation of peace and public order as the duty of the Sub-District Head who is

in the District sub-district is an effort to increase comfort for the community where the community's disease becomes a problem that tends to be a difficult obstacle to deal with so that the Sub-District head in carrying out his duties must have the potential to overcome it because it is very detrimental to the lives of the community especially young people as nation's nextgeneration.

In the implementation of all the activities of the administration of theDistrict level is coordinated directly by the Camat. And the purpose of coordinating is to encourage the smooth running of various activities at the sub-district level in the direction of improving the welf are and peace of the community. Incoordinating, the Camatusually provides boundaries or the government in accordance with the plans discussed at meetings with relevant parties. Related to the description of the Camat's general tasks above, it can be explained that one of the tasks that is currently under attention is coordinating efforts to organize peaceand publicorder. Therefore, in order to realize this, the Camat coordinated with subordinates and various related parties or other agencies working in the Sub-district area. This was done in order to create a peaceful and orderlyenvironment.

Understanding peace and order according to Ermaya Suradinata (2009), defines that: "Peace and order is a condition so that the government and the people can carry out activities safely, orderly and regularly. This peace and order can be disturbed by various causes and conditions including violation of applicable law, which disrupts public peace and order, natural disasters or disasters caused by humans or other organizations, and factors in the economic and financial fields."

Pangkalan Kerinci Subdistrict Pelalawan Regency has a population of 84,865 people with a population density of 1433 people $/ \mathrm{km}^{2}$. The total area of Pangkalan Kerinci Subdistrict is Pelalawan Regency with an area of 18,716.16 Ha. Pangkalan Kerinci Subdistrict is divided into 3 Kelurahan including Kerinci Barat Kelurahan, Kerinci Kota Kelurahan and Kerinci Timur Kelurahan, in addition it also consists of 4 Villages namely Bukit Agung Village, Kuala Terusan Village, Makmur Village and Rantau Baru Village.

Pelalawan Regency Regulation Number 9 Year 2016 Concerning Security and Public Order Article 1 is said to be point 27 Community Peace is a condition where the regional government and the people can carry out activities peacefully and comfortably, point 28 . Public Order is a condition where the regional government and the people can conduct activities in an orderly and orderly manner, and point 29 states that Public Peace and Order is a dynamic condition that allows Regional Governments and the public to carry out activities safely, peacefully, in an orderly and orderlymanner.

In Pelalawan Regency Regulation Number 81 Year 2016 Concerning Establishment of Organization and Working Procedure of Pelalawan District and Sub-District Section Section Four of the Peace and Order Section Section 15 explains that the Peace and Order Section has the task of fostering peace and order in the region and order has a duty.

a) Arrange program plans and budget sections for peace and order base don't hework plan and strategic plans of the District.

b) Coordinating matters of peace and public order and community protection. 
c) Conduct coordination with agencies regarding the programs and activities of peace and public order and community protection in the districtarea.

d) Carry out coordination with community shops and religious stores that are in the working area of the District to realize peace and public order in the community area of theDistrict.

e) Organizing peace and public order.

f) Follow, collect and prepare reports on events involving public order and public order.

g) Collecting and preparing data in the context of developing civil defense.

Coordinating the achievement of peace and order, of course, the Camat coordinated widely with local institutions, institute on sand communities. The form of coordination carried out by the Camat did not seem to provide maximum results, so he still met many in the district district activity - the activities or actions that took place that disturbed the community. Coordination is demanded to becarried out by the Camat by providing a goal of safe and orderly achievement by the community so that no unrest is felt by the community. The following is the coordination of the Camat in Pangkalan Kerinci Subdistrict on the application of Peace and Order in the community asfollows:

Table 1. Forms of Camat coordination with the institutions of community institutions and local communities in the Pangkalan Kerinci District in 2018

\begin{tabular}{|c|c|c|c|c|c|}
\hline No Coordination & $\begin{array}{l}\text { Institution, } \\
\text { Community institution }\end{array}$ & Form of Coordination & The place & Time & Date \\
\hline \multirow{4}{*}{ Camat } & Village / Village Head & $\begin{array}{l}\text { 1. Perform cooperation with } \\
\text { the Village keluarahan and } \\
\text { RT / RW-related public } \\
\text { tranquility andorder. } \\
\text { 2. Establish Kamling Posts in } \\
\text { Each Village. Receiving } \\
\text { reports from the public on } \\
\text { community institutions. }\end{array}$ & Camat office & $\begin{array}{l}\text { Each } \\
\text { month }\end{array}$ & Done \\
\hline & RT / RW & $\begin{array}{l}\text { 1. Cooperating with the } \\
\text { community } \\
\text { The local related } \\
\text { implementing peace } \\
\text { andorder. } \\
\text { 2. Receive reports from } \\
\text { thepublic. }\end{array}$ & Camat office & $\begin{array}{l}\text { Each } \\
\text { month }\end{array}$ & $\begin{array}{l}\text { Not Done } \\
\text { Routinely }\end{array}$ \\
\hline & Public & $\begin{array}{l}\text { 1. Running Ronda innings } \\
\text { 2. Providing reports related to } \\
\text { Peace and Order. }\end{array}$ & Camat office & $\begin{array}{l}\text { Each } \\
\text { month }\end{array}$ & $\begin{array}{l}\text { Not Done } \\
\text { Routinely }\end{array}$ \\
\hline & Polri and TNI & $\begin{array}{l}\text { Receive reports related to } \\
\text { Peace and Order from } \\
\text { thecommunity Make banners in } \\
\text { every village related to the } \\
\text { implementation of Peace and } \\
\text { order Provide strictsanctions for } \\
\text { violations of individuals or } \\
\text { individuals who are troubling } \\
\text { thecommunity. }\end{array}$ & Camat office & $\begin{array}{l}\text { Each } \\
\text { month }\end{array}$ & Done \\
\hline
\end{tabular}

Based on the explanation above, the form of Camat Coordination with the institutions of 
community institutions and local communities in the 2018 Pangkalan Kerinci Subdistrict which includes theVillage/Kelurahan Head, RT/RW, Community, Police and Local Armed Forces. It is known that the coordination of the Camat in the application of Peace and Order in the Pangkalan Kerinci Subdistrict has been held through meeting sheldevery month but it is known that RT / RW and the community have not optimally participated in meetings related to Peace and Order but only the Village / Lurah Head and the local police, which should The community must also attend the meeting because the community itself which is directly side by side related to security and order violations. The need for the Camat should bewiser in appealing and coordinating with the community so that the creation of safety and order is maintained by thecommunity.

To maintain order in the Pangkalan Kerinci District, the Camat has called on each village to build camp posts in each village to prevent environmental disturbance. From 2018 data in Pangkalan Kerinci Subdistrict the rearea number of Kamling post sin each village as the following table data:

Table 2. Number of Poskamling in Village / Kelurahan in Kecamatan PangkalanKerinci 2018

\begin{tabular}{cccc}
\hline No & Village / Village Name & total & Status \\
\hline 1 & Bukit Agung & 1 & Active \\
2 & Kuala Terusan & 2 & Active \\
3 & Prosperous & 1 & Not active \\
4 & West Kerinci Base & 1 & Not active \\
5 & City Kerinci Base & 1 & Not active \\
6 & East Kerinci Base & 1 & Not active \\
7 & RantauBaru & - & Not active \\
\hline & & Source: Pangkalan Kerinci Sub-District Office, 2019
\end{tabular}

Based on the table above, the number of Poskamling in the village / kelurahan in Pangkalan Kerinci Sub-District can be seen that from 7 villages / kelurahan in Pangkalan Kerinci Subdistrict, only 6 (six) villages / kelurahan own a poskamling, and from 6 (six) villages that have a poskamling only 2 (two) villages are active, namely in Bukit Agung and Kuala Terusan villages, while others are not active. Inactivity here means that it is not used for patrolling activities or as an Environmental Safety Post and because it is not functioning (not active) the Camat should turn directly in supervising whatever is the obstacle in the enforcement of security and involvement in the community.

The following describes some of the incidents involving peace in Pangkalan Kerinci District from 2017 to 2018 , namely:

Table 3. Peace Violation Data in PangkalanKerinci District 2017-2018

\begin{tabular}{lcccc}
\hline \multirow{2}{*}{ No } & Types of & Serenity & Information & \multicolumn{2}{c}{ Year } \\
\cline { 4 - 5 } & violations & & $\mathbf{2 0 1 7}$ & $\mathbf{2 0 1 8}$ \\
\hline 1 & Fight. & Citizens & 12 & 19 \\
2 & Theft. & Homes & 10 & 17 \\
\hline & & & Source: PangkalanKerinci Sector Police Station, 2019
\end{tabular}

From the table above Peace Violation Data in Pangkalan Kerinci Sub-District 2017- 2018 types of peace violations include Fighting, Theft. It is necessary for the Camat to be more responsive in relation to the events in the Sub-district territory with the cooperation efforts 
with the local police so that there is no unrest for the community.

Like wise also known violations of order that occurred in Pangkalan Kerinci District in 2017-2018 can be seen in the table below:

Table 4. Recapitulation of Order Violations in Pangkalan Kerinci District in 2017-2018

\begin{tabular}{|c|c|c|c|}
\hline Year & & Problems and Events & total \\
\hline \multirow{8}{*}{2017} & 1. & Order the street vendors on theshoulder of publicroads & 25 \\
\hline & 2. & Orderly Green Lane parks andpublic places (Pedagan) & 37 \\
\hline & 3. & Orderly Stall Mosquito Net in theMonth ofRahmadhan. & 17 \\
\hline & 4. & OrderlyGambling. & 19 \\
\hline & 5. & Orderly Tempe and TofuBusiness. & 5 \\
\hline & 6. & Conduct HomeKos & 5 \\
\hline & 7. & Karoke Place(Café). & 6 \\
\hline & 8. & Prostitution & 7 \\
\hline \multirow[t]{8}{*}{2018} & 1. & Order the street vendors on the shoulder of publicroads & 27 \\
\hline & 2. & Orderly Green Lane parks and public places (Pedagan) & 40 \\
\hline & 3. & Orderly Stall Mosquito Net in the Month of Rahmadhan. & 21 \\
\hline & 4. & OrderlyGambling. & 25 \\
\hline & 5. & Orderly Tempe and Tofu Business. & 7 \\
\hline & 6. & Conduct Home Kos & 7 \\
\hline & 7. & Karoke Place (Café). & 9 \\
\hline & 8. & Prostitution & 10 \\
\hline
\end{tabular}

Source: Pangkalan Kerinci Sub-District Office, 2019

Based on the table above Recapitulation of Order Violations in Pangkalan Kerinci Districtin 2017-2018. It is known that as explained in the table above, it indicates that public order in Pangkalan Kerinci Subdistrictis increasingly increasing in its problems so that in addressing this, it still needs more optimal handling. If seen from the scope of the events, the problem is the Camat's business in coordinating order together with the Community, Community Institutions and Village apparatus in order to achieve an orderlyenvironment.

Based on the explanation above, the need for coordination in order to maintain maximum peace and order carried out by the Camat so that it does not increase the anxiety felt by the community members. However, with problems and incidents still occurring, it is indicated that the existing coordination between the Camat and related institutions and community institutions has not been carried out to the maximum.

From the description above, it can be seen that the phenomenon in this study regarding the coordination of the Camat in carrying out the peace and orderincludes:

a) It is known that the Sub-District Head has not yet coordinated widely regarding peace and order in the community. This can be seen in table 2. It is known that the Peace and Order Coordination Meeting in the Pangkalan Kerinci Subdistrictis conducted every month, especially RT / RW and the community has not actively participated in meetings. Related to peace and order while RT/RW.

b) It is known that the Sub-District Head has not come down directly in the form of coordination with the Village Government broadly in relation to guarding the Kamling Post in every village so that the existing Kamling Post can operate properly every day so that by active participation the Kamling Post will provide safe and orderly order in the community.

c) It is known that there are still many violations of peace and order in the middle of the community seen in tables 3 and 4, this is due to the lack of Camat cooperation in the form 
of coordination in their handling so that violations of peace and order in each year still occur.

\section{Literature Review}

The role of the Camat in the administration of government is to carry out tasks whose function shave been explicitly compiled will facilitate the government bureaucracy in achieving the goals and objectives to be achieved, therefore to avoid the occurrence of bureaucratic functions as a result of irrational structures, not equipped by true employees. Really professional. Coordination relationships are needed so that in the organization there is a unity of action, unity of direction, adjustment and continuity between sections so that organizational goals can be achieved [1].

In Regulation of the Minister of Home Affairs Number 4 of 2010 concerning Guidelines for Integrated District Administrative Services Article 1 Paragraph 6 defines the Camat or other designation as the leader and coordinator of the administration of the government in the subdistrict working area which in carrying out it sduties obtains delegation of government authority from the Regent / Mayor to handle part of the autonomy matter regions and carry out general government duties.

Camat is the leader of the sub-district or as a district / city apparatus. The Camat is the coordinator of government administration in the sub-district area, is under and is responsible to the Bupati through the Regency / City Regional Secretary .

Where it says Law Number 23 Year 2014 Local government in Article 224 says:

a) A sub-district is headed by a head of sub-district called the sub-district who is under and is

responsible to the regent/mayor through the Regional secretary.

b) The regent / mayor is obliged to appoint a camat from civil servants who master the technical knowledge of the government and meet the staffing requirements in accordance with statutory provisions.

c) Appointment of sub-district head which is not in accordance with the provisions asreferredto inparagraph (2) shall be canceled by the governorasre presentative of the Central Government.

What needs to be underlined is that the Sub-District Administrator said, in the elucidation of article 224 of Law Number 23 of 2014 it is explained that what is meant by mastering the technical knowledge of government is evidenced by a diploma / government degree or professional certificate of civil service. The reality that applies today is that many sub-districts do not meet the requirements referred to above.

Coordination is the process of integrating goals and activities in separate units (departments or functional areas) of an organization to achieve organizational goals efficiently. Without coordination, individuals and departments will lose their grip on their role in the organization. They will begin to pursue their own interests, which often harm the achievement of overall organizational goals [2].

Coordination in development is essentially an effort to harmonize, unite and harmonize development activities carried out by various components, both government, private and community. In coordination, it should be applied to the entire development process, from the planning, implementation, control and supervision, to the evaluation. So in this case coordination covers the entire development process of development. Koordinasi is directing activities, integrate and coordinate the management elements and tasks subordinates in 
achieving organizational goals [3].

Good coordination can be seen as follows [4]:

a) There is responsibility. That the responsibility for coordination lies with the leadership. Leaders may not coordinate if they do not cooperate.

b) The process. This is because coordination is a leader's work that is sustainable and must be developed so that goals can be achieved properly.

c) Regular arrangements. Regular arrangements rather than group effort because coordination is a concept established with in the group, not to individual efforts, then from individuals who work together where coordination produces a group effort which is very important to achieve efficiency in implementing organization activity. Overlap, obscurity in work assignments is a sign of lack of coordination.

d) Unityofaction. Unity of action rather than effort means that he leader must regulate such efforts in individual activities so that there is harmony in achieving results. By arranging a planned schedule.

e) The purpose of coordination. Organizational goals are shared goals, unity of the effort to ask for an understanding for all individuals to participate in carrying out the objectives as a group in which they work.

Based on the explanation above, it is concluded that Coordination is something that contains an understanding of the spirit of "cooperation". The spirit of "cooperating" among fellow organizational units or agencies as well as among fellow officials in the implementation of regional development, is indeed very important as a foundation for the success of the development effort. However, the spirit of cooperation alone does not guarantee the objectives to beachieved.

Peace and Order is a condition so that the government and the people can carry out activities safely, orderly and regularly. The peace and order can be disturbed by various causes and conditionsin cluding the violation of applicablelaw, which causes the disturbance of peace and order of the people [5].

\section{Research Method}

This type of research used in this research is descriptive qualitative. Descriptive research is research that focuses on the problems or phenomena that exist when the research is conducted, then describes the facts and explains the state of the object of research in accordance with reality as it is and tries to analyze to provide its truth based on data obtained by Sudarman [6]. In this study the key informants in this study were individuals who were involved in Peace and Order in the Pangkalan Kerinci District. The Camat, the Village/Kelurahan Head.

\section{Result and Discussion}

The author uses several indicators in the measurement of the implementation of coordinating efforts to peace and public order in the District of Pangkalan Kerinci, including:

\subsection{Responsibility}

Coordination responsibility is the leader's main task, including coordination responsibility. 
Coordination responsibility has been carried out by the Pangkalan Kerinci Sub-District where the Camat gives the authority of coordination to every Government agency in the District, this is done because of the wide range of management that the Camat has to go through to achieve coordination. The main supporting factor in coordination is none other than communication with communication so that the coordination process can run, where it is known that good communication activities will certainly facilitate the coordination process through the delivery, appeal of messages or the contents and objectives, and the benefits to be achieved in the coordination.

Based on the interview results it can be concluded that the Camat who plays the role of leader must be able to coordinate with subordinates, where the Camat must be able to influence subordinates through the leadership process. Leadership can be interpreted as a process or activity to influence the activities of a person or group of people in an effort to achieve a predetermined goal.

Based on the results of the interview it was found that the village head had received coordination from the Camat regarding peace and order but the peace and order effort delivered by the Camat was only anappealand the widespreadab sence of steamand actions taken in the handling of peace and order in the village. The implementation of peace and order coordination is quite well known that the Camat coordinates for each institution or agency in the District. Of course, if there is a disturbance of peace and public order, then every institution and agency, including Village officials are expected to provider eports so that it can be resolved and not disturb public order.

\subsection{The Process}

The process is an activity that is ongoing, or continuous, and needs to be developed until the goal of the coordination is achieved. While the coordination process carried out in an effort to administer peace and public order is to provide a report where the coordinated section provides a report to the coordinating party regarding an incident.

Based on the results of the interview sit was found that the coordination process that is being carried out in achieving the implementation of peace and public order is to provide areport, where the coordinated section reports to the coordinating party about an incident. In this study the village head reports to the Camat about the inconvenience felt by the public, with the existence of the disturbance, it is feared that it can disturb the peace and public order. Based on the results of the interview it was found that the Pangkalan Kerinci Timur. Urban Village had provided a report related to peace and order for the Camat as a form of coordination by the village head but the report given had not been soslui in handling the problems in the village so that the determination of the peaceful and orderly village had not been going well .

The form of the report submitted by the Village in this research is related to the existence of a café business under the guise of prostitution on Jalan Lingkar, and it is known that the existence of the café is very disturbing for the people in the café because there are karaoke activities until dawn, and there are many women in the night. This unsettled the people with the noise from the café and many local residents who spent the night at the place, especially young men, so troubling their families. This is very contrary to the rules of peace and order in the middle of the community.

With the appeals and reports from the community, the Subdistrict provides steps and efforts to resolve problems that are troubling the community that occur as a process that must involve all relevant elements. With the report, the Sub-District can find out the problems that 
occur in the village, and can find solutions and solutions to the problems that are happening.

The role carried out by the Subdistrict by holding a deliberation in the form of a mediator is one form of the process carried out in an effort to resolve the problem that has occurred, each process undertaken must be a process that leads to the resolution of the problem. This role relates to the approach to achieving effective coordination through enhancing potential coordination by holding meetings relating to problem solving and decision making.

\subsection{Regular Arrangements}

Regular arrangement is a concept that involves a group consisting of many people, and not as an individual activity. Each individual works together and coordinates to produce a group effort asefficiency, and effectiveness in carrying out organizational activities. Asan organization that serves community life that is full of dynamics so that the Sub-Districtfaces many problems and must be able to carry out every role that has been delegated as a formof duties and responsibilities.

The Subdistrict Administration, the Village is the administrative area of the Subdistrict, however, the Village has direct accountability to the Regent as the Regional leader, but every problem that occurs in the Village will be resolved based on administrative territory, so the Village and Subdistrict must coordinate in the effort to resolve any existing problems in the region as Government partners.

Based on the results of the interview it was found that the implementation of the Camat's task of coordinating peace and order was based on regulations delegated to the Sub- District and being accountable to the Bupati and undertaking coordinating efforts for the government brought me like a Kelurahan and Village even though indirectly accountability to the District but together with the Regent as the Regional leader but, every problem that occurs in the village will be resolved based on administrative areas, so that villages and sub- districts must coordinate in the effort to solve every problem in their territory as Government partners in order to establish efforts to establish regulations, manage peace and order in the Pangkalan Kerinci District.

Based on the results of the interview it was found that the Head of the RantauBaru Village received coordination by the Camat in relation to peace and order but the form of coordination delivered did not go directly to the village / kelurahan residents and the community in the efforts of peaceful and orderly villages but only appeals when there was a Camat dictatorial meeting. this can be seen that the coordination given by the Camat has not given strength to the Village / Kelurahan in conducting a safe and orderly Desa / Kelurahan. Everything related to social life is regulated in law. The purpose of the regulationis for the sake of creating order and order and security for each community member together. Especially for any violations related to peace and order in Pangkalan Kerinci Subdistrict, they must be resolved in accordance with established regulations.

Implementation of peace and order in Pangkalan Kerinci Subdistrict based on the stipulation of Pelalawan Regency Regulation Number 9 Year 2016 concerning Securityand Public Order Article 1 is said to be point 27 Community Peace is a situation where the regional government and the people can carry out activities peacefully and comfortably, point 28 Public Order is a situation where the Regional Government and the people can carry out activities in an orderly and orderly manner, and point 29 states that Public Peace and Public Order is a dynamic condition that enables the Regional Government and the community to carry out activities safely, peacefully, in an orderly and orderlymanner.

That is also stated in Article 4. The scope of handling Peace and Public Order regulated in 
this Regional Regulation are:

a) Orderly prostitution /prostitution;

b) Orderly alcoholic drinks class A, namely alcoholic drinks with ethanol $(\mathrm{C} 2 \mathrm{H} 50 \mathrm{H})$ content of $1 \%$ (one percent) up to $5 \%$ (five percent), class Balcoholic drinks are alcoholic drinks with ethanol $(\mathrm{C} 2 \mathrm{H} 50 \mathrm{H})$ content of more than $5 \%$ (five percent) to with $20 \%$ (twenty percent), class $\mathrm{C}$ alcoholic drinks, namely alcoholic drinks with ethanol $(\mathrm{C} 2 \mathrm{H} 50 \mathrm{H})$ content of more than $20 \%$ (twenty) up to $55 \%$ (fifty-five percent);

c) Tertb Narcotics and Drugs ;

d) Intoxicating traditional drinks (Tuak);

e) Tertip Suction Glue and other effective substances;

f) Orderly business in cafes, karaoke and billiards;

g) Orderly place of entertainment;

h) Social order;

i) Orderly roads and public transportation;

j) Orderly green lanes, parks and public places;

k) Orderly cleanliness and beauty of the environment;

1) Orderly street vendors;

m) Orderly mosquito net shop in the month ofRamadan;

n) Orderly boarding / rental house;

o) Orderly Social Tuna and Street Children;

p) Orderly Gambling;

Based on violations that occurred in the Pangkalan Kerinci Subdistrict established Pelalawan District Regulation Number 9 Year 2016 Regarding Security and Public Order,it can be seen that types of peace and order violations at the Kerinci base include tranquility violations including the sale of illegal drugs (Narcotics), Liquor Sellers, public order includes. Order of Street Vendors on the shoulder of public roads, Order of Green Lane parks and public places (Pedagan), Order of Warung nets in the Month of Rahmadhan, Order of Gambling, Order of Tempe and Tofu Enterprises. Theft, Orderly Boarding House, Karoke Place (Café), Prostitution. The implementation of peace and order regulations in the Kerinci Subdistrict should be done more by coordinating well so that problems related to peace and order can be controlled so that it does not disturb the community and harm the community so that the creation of a safe and secure community environment .

\subsection{Unity of Action}

Unity of action is the unity of efforts, individuals in this case, the leadership must regulate all efforts, individual activities so that there is harmony in achieving results. Harmony can be obtained by planning without unity of action between the divisions in charge, efforts to implement coordination in an effort to organize peace, and public order will be difficult. Peace and public order will be achieved if coordination is carried out with the unity of action from each part, because coordination and unity of action are interrelated activities.

Based on the results of the interview it was found that the Pangkalan Kerinci Sub- District had coordinated by carrying out a unity of actions that occurred with the Village Head, Kelurahan and Village Community Institutions in handling peace and order disturbance felt by the community, then the Pangkalan Kerinci Sub-District as the District leader had coordinated in creating a unit action aimed at resolving the problem that is happening in the community.

Based on the result soft he interview, it was found that the Head of the Rantau Baru Village had carried out a unifiedact in the hand ling of peace and order which was coordinated 
by the Camat, where the Village Head had made peace and order efforts in setting up a pos kamling and reporting to the Camat about peace and order issues in theVillage.

The unity of action taken by the Pangkalan Kerinci Sub-District Head is good enough by creating a guideline or guideline for the implementation of peace and order, this serves as a guideline in carrying out tasks in accordance with the field undertaken by the Camat. While the unity of action taken by the Camatin resolving problems that occur in the community is coordination in the form of holding meetings, and with the meeting can achieve a unity of action through deliberation. However, this was felt to be less effective, because at the time of the meeting or meeting, not all representatives of the agencies and village officials could attend. The absence of some of the Village apparatus and agencies in the meeting which was used as an effort to create a unity of action, was a factor influencing the lack of optimal coordination. In addition the form of meetings and meetings held in an effort to coordinate, the Camat should create a regulation that regulates the entire community in order to create peace and public order.

It is expected that there are rules that are binding and only apply to people whose scope is smaller in order to create an orderly situation, this is considered more capable and effective in its enforcement efforts. Coordination in the effort to unify actions by the Camat was quite good but in the effort storegulate the community specifically so as to avoid conflict there was not yet. Basically, to achieve peace and order among the people is the awareness of each individual in creating a peaceful and orderly atmosphere.

\subsection{Purpose of Coordination}

The purpose of coordination, is the implementation of organizational programs which are shared goals, so that all individuals with in the organization are expected to beable to coordinate in implementing the objectives as joint business activities. Each implementation of the tasks given and carried out through coordination of the division of tasks, this can make coordination more directed, making it easier to achieve goals. Coordination is done by giving emphasis in achievinggoals.

The creation of good coordination will certainly lead to facilitate the establishment of peace and order among the community which is also the goal of the organization. Coordination is known to be inseparable from the existence of good communication activities so that this is also a factor that influences how the Camat's role in coordinating to the part that is coordinated with good communication will certainly result in better coordination.

Based on the results of the interview it was found that the Pangkalan Kerinci Sub- District had coordinated through communication with the Village Head and Keluharan and the Village Society Institution by providing appeals and suggestions so that every problem in the community was resolved by mutual deliberation.

Based on the result soft he interview it was found that the Pangkalan Kerinci Timur Urban Village had communicated with the Camat with the Camat giving an appeal related to peace and order but the Camat had not set the time for communication with the Village / Kelurahan in terms of meetings related to efforts to settle the peace and order in the community so that communication was given by the Camat only an appeal.

The communication carried out by the Camat in carrying out its duties in peace and public order has not been carried out properly while it is known that Communication within the organization is one of the leaders' respon sibilities where in with in the organization whose structure develops there will be various communication problems, this is certainly due to differences in function, and interests for every person. The role ofthe leader as a 
communicator in coordinating is very important this is because the leader how ill determine a direction in achieving organizational goals. The intended leadership is how the Camat's role influences the individual through the communication process to achieve certaingoals.

The implementation of the coordination process in the effort to maintain peace and public order there are several indicators besides internal factors, which are found in individual Camat as leaders, there are also internal factors, which cause the Camat's suboptimal role in achieving its objectives, besides the most important thing that must be considered is none other than elements of communication activities inherent in the implementation of coordination, because coordination will never take place without the existence of good communication between the implementing elements of the coordination .

\section{Conclusion}

The implementation of Camat tasks in peace and order coordination in Pangkalan Kerinci Subdistrict is quite good, where the Pangkalan Kerinci Camat has done various ways through coordination with the Village/Kelurahan Government and Community and Police Institutions in Pangkalan Kerinci Subdistrict, and even coordinating with the community which is the object of the object services performed by the District. Where the sub-district head is present in an undisciplined and orderly manner established by the community and receives reports on security disturbances, as the head of the sub-district always tries to provide a solution by referring to the applicable regulations, as well as making de liberations involving various parties involved in achieving peace and order. But the fact that there is a sense of comfort in the Pangkalan Kerinci Subdistrict community has not been felt by some residents because of the internal factors of the Sub-District Head who have many Camat tasks so as to make the implementation of peace and order in the community as well as external factors visible that the Village/Kelurahan Government has not participated in participating with both in the coordination of achieving peace and order handling in the community.

\section{Recomendation}

First, the Regent should collect data on the results of the performance of the Camat in carrying out the task of peace and order in the community. Secondly, it is expected that the Camat will further improve coordination in the effort to maintain peace and public order in Pangkalan Kerinci District . Third, the need for the Sub-District Head to determine the time of meeting activities in the organization of peace and order so that the village / kelurahan government can know when the meeting activities will take place. Fourth, the need for the Camat to provide guidance to the Village apparatus related to the handling of peace and order in his village in order to have knowledge and abilities in the effort to handle peace and order in the community. Fifth, the need for the Sub- District Head to come down directly to the community by providing socialization related to cooperation in the handling of peace and order in the community and the existence of community actions to report to the District if there is a problem in his village . 


\section{References}

[1] Kaho, 2002. Looking for Forms of Regional Autonomy, RinekaCipta, Jakarta.

[2] Handoko, T. Hani, 1997, Management, Issue 2, Yogyakarta, BPFE.

[3] Hasibuan, Malayu, SP, 2005 , Human Resource Management, Jakarta, GunungAgung.

[4] Handayaningrat. Soewarno, 2002 ,Pengatar Study of Administrative and Management Studies , Jakarta, GunungAgung.

[5] Ermaya, 2000, Government Management and Regional Autonomy . Jakarta. Rajawali.

[6] Sudarman, Danin. 2002, Becoming a Qualitative Researcher, Bandung, Loyal Reader. 